\title{
INFORMATION SUPPORT OF THE LABOR MARKET OF UKRAINE AND EASTERN EUROPE: INNOVATION ASPECTS
}

\author{
Olena Hryshko ${ }^{1}$
}

\begin{abstract}
Introduction. The processes of informatization of society, reform of state institutions and transformation of the economic system of Ukraine identify new problems and set new challenges for regulating the labor market and employment on the basis of public-private partnership, including by bringing to all labor market actors relevant information from verified sources. Given the signing of the Association Agreement with the European Union, Ukraine should take into account the experience of Eastern European countries that have been in similar transition conditions and have shown significant progress, in particular in overcoming the problems and threats in the labor markets that they have encountered in the process of European integration. Purpose and objectives. There is a necessity to justify the expediency of integration of information of subjects in the labor market of Ukraine for the purpose of formation of uniform information support of the labor market that will promote legal productive employment of citizens. Methodology. The article is based on international legal acts, laws and bylaws of Ukraine in the field of employment and regulation of labor market processes in the context of the functioning of a single information environment, formed on the basis of public-private partnership. Both general and special methods were used for the research: methods of analysis and synthesis, descriptive method, methods of induction and deduction. Results. The article analyzes the regulation of the European labor market by integrating the capabilities of national public employment services, the implementation of equal opportunities in free labor mobility for European workers. The data and experience of the countries of Eastern Europe are given. The institutional and legislative aspects of the functioning of private mediation in the domestic labor market are considered and it is proved that in Ukraine there is currently no regulatory influence of the state on the activities of private mediation in this market, and regulatory support in this area is imperfect. It is studied that information flows of private intermediaries, including job search and recruiting websites, operate independently of state intermediaries, and the public does not fully have up-to-date information on the state and needs of the domestic labor market. The article highlights the role of the government and the State Employment Service in the formation of information support of the labor market, compares the published data, provides relevant recommendations of the International Labor Organization and foreign experience. Conclusions. The information published in Ukraine by private labor market intermediaries needs full attention, as its connection with informal employment is not excluded. Given the impact of globalization challenges on the functioning and development of the domestic labor market, it is proposed to standardize the activities of private labor market intermediaries, including job search and recruiting websites, by including their data on labor supply and demand in the domestic labor market. For Ukraine, the experience of the European countries in cooperation between public and private intermediaries in the labor market, based on the creation of single information support of the labor market, including through joining the EURES system, is relevant.
\end{abstract}

Key words: job search and recruiting website, State Employment Service, information support, labor market intermediaries, labor market.

JEL Classification: J20, J22, J28, J60, J68

\section{Introduction}

Nowadays, there are more and more appeals of job seekers for services to online labor market intermediaries who provide employment services. For employers who offer vacancies and seek to fill them

\footnotetext{
Corresponding author:

${ }^{1}$ Ukrainian State Employment Service Training Institute, Ukraine.

E-mail: elenapetrovna222@gmail.com

ORCID: https://orcid.org/0000-0002-5711-897X
}

as soon as possible, the services of such private labor market intermediaries save time on recruitment and maintenance costs of HR staff. It is generally accepted in the world that private labor market intermediaries help reduce unemployment and increase employment, 
as evidenced by the successful experience of the European countries. In Ukraine, the services of private intermediaries are in demand, but their improper legal regulation, failure to ensure control over their activities results in the continued existence of informal labor relations in Ukraine, violation of workers' rights in the course of their employment. Job search and recruiting activities in this area remain poorly understood, and there is no information interaction between the public and private sectors. All this requires in-depth analysis of the experience of the European countries and search of new modern solutions to regulate the interaction of private mediation with the state to ensure the effective functioning and development of the labor market, regulation of relations between employers and employees, development of qualitative forecasts of economic development and related market changes, facilitation of the performance of educational services, promotion of productive employment, reduction of informal labor relations.

\section{Mechanisms for regulating labor markets based on public-private partnerships using information technology}

The questions of the functioning of the labor market, its functions and mechanisms of regulation, the implementation of employment policy in the direction of reducing unemployment and increasing employment have been studied in the works by prominent economists A. Marshall, A. Pigou, J. Rubery and F. Wilkinson, J. Stiglitz, J. Kornai, R. Ehrenberg and R. Smith. For our study, the conclusions of prominent American scientists - Nobel Laureates in Economics G. Akerlof, M. Spence and J. Stiglitz - are very important. They prove "the interdependence of economic crises with asymmetric information flows, lack of transparency of the information environment and the absence or inefficiency of institutions designed to address the regulation of this market because free movement of market resources is impossible without free movement of information" (Akerlof, 1970). Meanwhile, as the current state of the labor market of Ukraine is characterized by an increasing imbalance between supply and demand of labor, excessive supply of educational services in their mismatch with quantitative and qualitative parameters of demand, reduced motivation of able-bodied people to productive legal employment within Ukraine, excessive labor emigration, there is a position of F. Schneider that "it is the policy of state regulation that makes it possible to neutralize the numerous destructive processes and undesirable deviations that periodically interrupt and distort the movement of the economic cycle" (Schneider, 2012).

Domestic scientists define that the modernization of the labor market is not carried out effectively enough
(Irtyshcheva, 2020); they agree with foreign scientists that in modern conditions, the labor market regulation mechanism should combine elements of self-regulation with state influence on labor market and employment processes; they also prove that "it is inexpedient to be limited only to market self-regulators, the market mechanism alone cannot provide full, productive and freely chosen employment" (Petrova, 1996). At the same time, it is noted that the mechanism of information support and communication of the State Employment Service should provide for the focus of information and communication resources on various subjects of employment: employers, employment intermediaries and other stakeholders (Lutai, 2017).

Employment in Europe is determined by an independent value that ensures not only material wellbeing but also social harmony of all the strata of the population in society. Labor mobility in the European Employment Strategy is not only a fundamental right but also a tool to help the labor market adapt to constant and dynamic change. The European Employment Services has launched the EURES portal as a tool to improve the regulation of the European labor market by integrating the capabilities of national public employment services, realizing equal opportunities in free labor mobility for European workers, eliminating language barriers, cultural differences, bureaucratic problems, differences in labor legislation and with the help of the recognition of educational certificates of other countries. Using this portal, job seekers including migrant workers have the opportunity to obtain reliable information on vacancies from employers in the EU countries, as well as to compare their professional data to employment. In March 2021, EURES brought together around 30 European countries, with 2.8 million job offers, $820,000 \mathrm{CVs}, 5,000$ cooperating employers and 1,000 Euroconsultants from the public employment services of each Member State or from EURES partner organizations. At the same time, the base of vacancies from the Czech Republic, Slovenia, and Sweden is filled with job offers formed by the state employment services of these countries. Other countries submit those vacancies to EURES that have been identified by employers suitable for foreign applicants; in practical terms, this means that these are jobs with an international component. The portal provides communication with EURES Advisers, who provide advice to entities interested in entering the European labor market.

In Ukraine, the information component of the domestic labor market consisting of data from private agencies and job search websites and staff has long remained understudied. At the same time, the world community recognizes that "well-regulated and organized private employment agencies increase the workforce by creating additional jobs, promoting a variety of forms of employment, facilitating 
employment for people with disabilities, and reducing informal employment” (Ghada, 2011).

Cooperation between public and private labor market intermediaries in many countries is based on "the creation of a single information support of the labor market through access to the database of vacancies and CVs of individuals" (Abdusaidov, 2020). Italian law provides for the accession of all public and private employment agencies to the national computer network. This network is used to summarize and exchange available information about the nature, demand and supply of labor to limit and eliminate services provided by the "gray market" (Rymar, 2015). There are 10,273 employment agencies in France, which operate in all employment sectors and regulate the labor market at the regional and local levels. In 2019, they offered more than 21 million employment opportunities, $44 \%$ of which were temporary. Since January 2005, employment agencies have been able to recruit staff on behalf of companies, posting information in a single system in partnership with the public employment service Pôle Emploi, AFPA, and local authorities (Prism'emploi - Rapport économique et social, 2019).

In Ukraine, the legislative support of private intermediaries in the labor market is not harmonized with international law, there is no regulatory influence of the state on the activities of private mediation in this market, regulatory support in this area is incomplete and helps the autonomy of private labor market intermediaries and job search and recruiting websites. Meanwhile, at the World Economic Forum in Davos, Head of the Center for New Economy and Society S. Zahidi in his report proposed to address the problems of excessive concentration in the market of online platforms including by improving the regulation of their activities (Zahidi, 2019). The International Labor Organization holds the same point; the organization continues to focus on the growing global spread of "disguised" forms of labor relations (Mandl, 2015), which are circulating on online platforms.
The processes of informatization of society, reform of state institutions and transformation of the economic system of Ukraine identify new problems and set new challenges for regulating the labor market and employment on the basis of public-private partnership, including by bringing to all labor market actors relevant information from verified sources. The formation of a single information environment of the labor market will create tools for public administration to achieve the most effective regulatory influence on processes and phenomena in the labor market.

\section{Analysis of information support of the labor market of Eastern European countries}

European integration aspirations of Ukraine stimulate the country to actively develop information society, "digitalize" the economy, adapt the labor market to globalization risks, informatize social and administrative services. Domestic scientists predict threats to the opening of European labor markets for Ukrainians and catastrophic consequences for the domestic economy; they propose measures to artificially limit, delay and deter certain European integration processes, draw analogies of "destructive" consequences of European integration for the Baltic States and the Warsaw Pact connected with the market transformations, denationalization and privatization, introduction of efficiency systems and high standards for labor economy. The dynamics of unemployment in Eastern European countries from 2010 to 2020 is presented in Table 1 .

Compared to the situation in the EU as a whole, there is a kinship in the chronology of changes in the represented countries of Eastern Europe. In the period from 2015 to 2018, slightly higher rates were observed in Slovakia and Latvia, but every year during this period they were also improved for Poland, the Czech Republic, Hungary, Bulgaria, and Romania. In 2019, all the countries assessed without exception reached the unemployment rate below the European Union average. In 2020, economic factors were joined by circumstances such as the COVID-19 pandemic.

Table 1

Unemployment rate in Eastern European countries from 2010 to 2020 from the economically active population

\begin{tabular}{|l|c|c|c|c|c|c|c|c|c|c|}
\hline Country/year & 2011 & 2012 & 2013 & 2014 & 2015 & 2016 & 2017 & 2018 & 2019 & 2020 \\
\hline EU & 9.9 & 10.8 & 11.4 & 10.8 & 10.0 & 9.1 & 8.1 & 7.2 & 6.7 & 7.0 \\
\hline Bulgaria & 11.3 & 12.3 & 13.0 & 11.4 & 9.2 & 7.6 & 6.2 & 5.2 & 4.2 & 5.1 \\
\hline Estonia & 12.3 & 10.0 & 8.6 & 7.4 & 6.2 & 6.8 & 5.8 & 5.4 & 4.4 & 6.8 \\
\hline Latvia & 16.2 & 15.0 & 11.9 & 10.8 & 9.9 & 9.6 & 8.7 & 7.4 & 6.3 & 8.1 \\
\hline Lithuania & 15.4 & 13.4 & 11.8 & 10.7 & 9.1 & 7.9 & 7.1 & 6.2 & 6.3 & 8.5 \\
\hline Poland & 9.7 & 10.1 & 10.3 & 9.0 & 7.5 & 6.2 & 4.9 & 3.9 & 3.3 & 3.2 \\
\hline Romania & 7.2 & 6.8 & 7.1 & 6.8 & 6.8 & 5.9 & 4.9 & 4.2 & 3.9 & 5.0 \\
\hline Slovakia & 13.6 & 14.0 & 14.2 & 13.2 & 11.5 & 9.7 & 8.1 & 6.5 & 5.8 & 6.7 \\
\hline Hungary & 11.0 & 11.0 & 10.2 & 7.7 & 6.8 & 5.1 & 4.2 & 3.7 & 3.4 & 4.3 \\
\hline Czech Republic & 6.7 & 7.0 & 7.0 & 6.1 & 5.1 & 4.0 & 2.9 & 2.2 & 2.0 & 2.6 \\
\hline
\end{tabular}


Currently, it is difficult to assess and predict their influence. At the end of 2020, the unemployment rate in Ukraine was 9.5\%. The lowest unemployment rate in the European Union as of 2021 is shown by the Czech Republic (2.6\%), Poland, Germany (3.2\%), Hungary (4.3\%), which is on par with more successful countries such as the Netherlands and Norway. It should be noted that in the European countries this is facilitated by measures of active state regulation of the labor market and migration policy processes.

Given the signing of the Association Agreement with the European Union, Ukraine should take into account the experience of Eastern European countries that have been in similar transition conditions and have shown significant progress, in particular in overcoming the problems and threats in the labor markets that they have encountered in the process of European integration. If we summarize them, we systematize the main priority response mechanisms of the Ukrainian labor market to the challenges of globalization:

- keeping an open and legalized labor market;

- implementation of accessible, targeted and operational adult education programs;

- stimulating the remigration of domestic specialists from abroad, the systematic and controlled involvement of foreign specialists;

- taking measures to reduce the share of shadow employment, in particular by regulating the activities of job search and recruiting websites.

Ukraine should realize the possibility of joining the employment service to the EURES system, and in particular to its local opportunities, the creation of EURES Cross-border Partnerships, as EURES plays a particularly important role in border crossings more than 1 million people live in one EU country and work in another. EURES Cross-Border Partnerships are groups of members and partners of EURES and, where appropriate, other stakeholders outside the EURES network. The groups are involved in long-term cross-border cooperation to support the mobility of employees working abroad and their employers. They typically include regional or local employment services, the social partners, and other organizations, such as chambers of commerce, educational and training establishments, local governments from at least two neighboring member states. Such agreements existed and operated during the times of active economic transformations between Poland and Germany. For Ukraine, these may be agreements with Poland, Hungary, Slovakia, and other countries. Such agreements will be based on mutual benefit and trust on both sides. The information exchange on vacancies and applicants should be set up through the State Employment Service of Ukraine, which is able to verify the employer and job seeker, working conditions and compliance with these requirements of applicants on site, as well as to some extent control the labor service of foreigners. On the other hand, providing information on the most popular and well-paid vacancies in Ukraine to the employment services of other countries will create additional opportunities for the return of migrant workers.

\section{Analysis of information support of the labor market in Ukraine}

In Ukraine, private labor intermediaries in the labor market have always acted autonomously from state institutions, "there was fierce competition between the participants, there was no motivation to cooperate, as well as to unite efforts to improve the situation in the labor market and employment in general" (Marchenko, 2013). The same situation remains to this day.

Convention No. 181 of the International Labor Organization (ILO) of 1997 recognizes that private employment agencies can play a positive role in the labor market, especially in the context of changing forms of employment in adapting the labor market to the needs of the time. A special section of Recommendations No. 188, provides for cooperation between them, including through the creation of joint bodies whose activities are aimed at forming a coordinated policy in the labor market, and among the possible forms of cooperation, there are the exchange of information and use of common terminology, organization of joint projects in the field of training and integration of the unemployed into the labor market (ILO Recommendation, 1997).

To normalize mediation activities in the domestic labor market, the Law of Ukraine "On Employment of Population" dated 2012 defines the concept of an entity that provides services to mediation in employment, allows to form unions (associations), which have the right to submit proposals for the formation and implementation of state policy in the field of employment. Among the main directions of state policy in the field of employment, legislation determines coordination and control of business entities that provide services with mediation in employment, their cooperation with the State Employment Service, which faces the task of formation of a database of vacancies (positions) on the basis of information received from employers and business entities that provide services with mediation in employment and public authorities; maintaining a List of business entities that provide employment mediation services. It should be noted that to date, a single database on job vacancies involving the public and private sectors is not being formed.

The organization of interaction of private intermediaries with the State Employment Service is currently maintained in such a way that business entity submits an application in the appropriate form that is the basis for entering data into List of business entities that employment mediation services, and those 
that hire employees for further work in Ukraine with other employers. The List is published on the official website of the State Employment Service. In particular, the following information on the service provider is given: name; type of economic activity, in particular: activity of employment agencies, activity of temporary employment agencies or other activity on provision of labor resources; location; last name and first name of the head; phone number; the number of the permit or license is given if the subject simultaneously provides services for mediation in employment abroad. In general, such published data are uninformative for users, as the entity is not informed about the results of its activities, in particular, such as the number of employed citizens, the number of vacancies operated by the intermediary, the number of employers with whom recruitment agreements are concluded, employment efficiency rating, service user feedback, etc.

The legislation of Ukraine stipulates that all business entities that provide employment mediation services quarterly inform the State Employment Service with a report on the form No.1-ПА "Information on the number of employed citizens by business entities that provide employment mediation services" (Table 2).

In Ukraine, there are about 90 virtual Internet intermediaries in the form of job search and recruiting websites, the activities of which are currently not regulated by law, except the other employment intermediaries. They can be conditionally divided into groups: private websites and their regional or local pages, job aggregators, specialized industry resources, bulletin boards, subsites, etc. Their functionality includes the provision of services for simplified registration: automatic selection of job offers and employers resumes; filtering and sorting data by date of publication, level of wages, type of employment, etc. It is studied that on the pages of these websites there is provided no information on the entity on whose behalf employment mediation services are provided, thus the registration of such websites is carried out without verification of registration data of the entity according to two open registers: 1) the Unified State Register of Legal Entities, Individual Entrepreneurs and Public Organizations and 2) List of business entities that provide employment mediation services and business entities that hire employees for further work in Ukraine with other employers. Data on the registered quantitative indicators on the demand for employees of the State Employment Service and the most rated job search and recruiting websites (work.ua, robota.ua, grc. ua, jobs.ua) in Ukraine are presented in Figure 1.

In 2019, the State Employment Service registered 1.2 million vacancies from employers, while on one of the job search and recruiting websites (robota.ua), employers announced 0.7 million vacancies. In particular, on such websites, the employer is not limited to the number of vacancies registered, it is possible to register the same vacancy in several sections of the same site, or on different websites of the relevant specialization. At the same time, ILO Recommendation No.188 stipulates that the competent authority must combat deceptive advertising practices and false advertising, including fake job ads. Currently in Ukraine, no public body is authorized to exercise such control. On the other hand, job search and recruiting websites do not exercise control over the prompt removal of the vacancy in the event of its staffing, which creates infoglud for users.

\section{Problems and prospects for development of information support of the labor market in Ukraine}

Bylaws in Ukraine do not provide for the submission of private labor market intermediaries, including job search and recruiting websites, to the State Employment Service, information about the vacancies received from employers, they are not involved in the formation of

Table 2

Number of domestic business entities that provided employment services in 2015-2020

\begin{tabular}{|c|c|c|c|c|}
\hline \multirow{2}{*}{ Year } & \multirow{2}{*}{$\begin{array}{c}\text { Number of entities that provided } \\
\text { employment services, units* }\end{array}$} & $\begin{array}{c}\text { provide employment } \\
\text { in Ukraine }\end{array}$ & $\begin{array}{c}\text { include employees hired for further } \\
\text { work in Ukraine with other employers }\end{array}$ & $\begin{array}{c}\text { provide employment } \\
\text { abroad }\end{array}$ \\
\hline A & 1 & 2 & 3 & 40 \\
\hline 2015 & 549 & 169 & 118 & 322 \\
\hline 2016 & 597 & 170 & 155 & 359 \\
\hline 2017 & 742 & 214 & 238 \\
\hline 2018 & 984 & 318 & 464 \\
\hline $2019 * *$ & 1153 & 287 & 511 \\
\hline 2020 & 1225 & 325 & 544 \\
\hline
\end{tabular}

* column 1 is not the sum of columns 2,3 , 4, due to the fact that some entities provide several types of services simultaneously.

** in 2019, a new form and procedure for its provision on a quarterly basis starting from the report for the third quarter was approved by the order of the Ministry of Social Policy of Ukraine No. 851 dated June 3, 2019

Source: compiled by the author according to the State Employment Service 


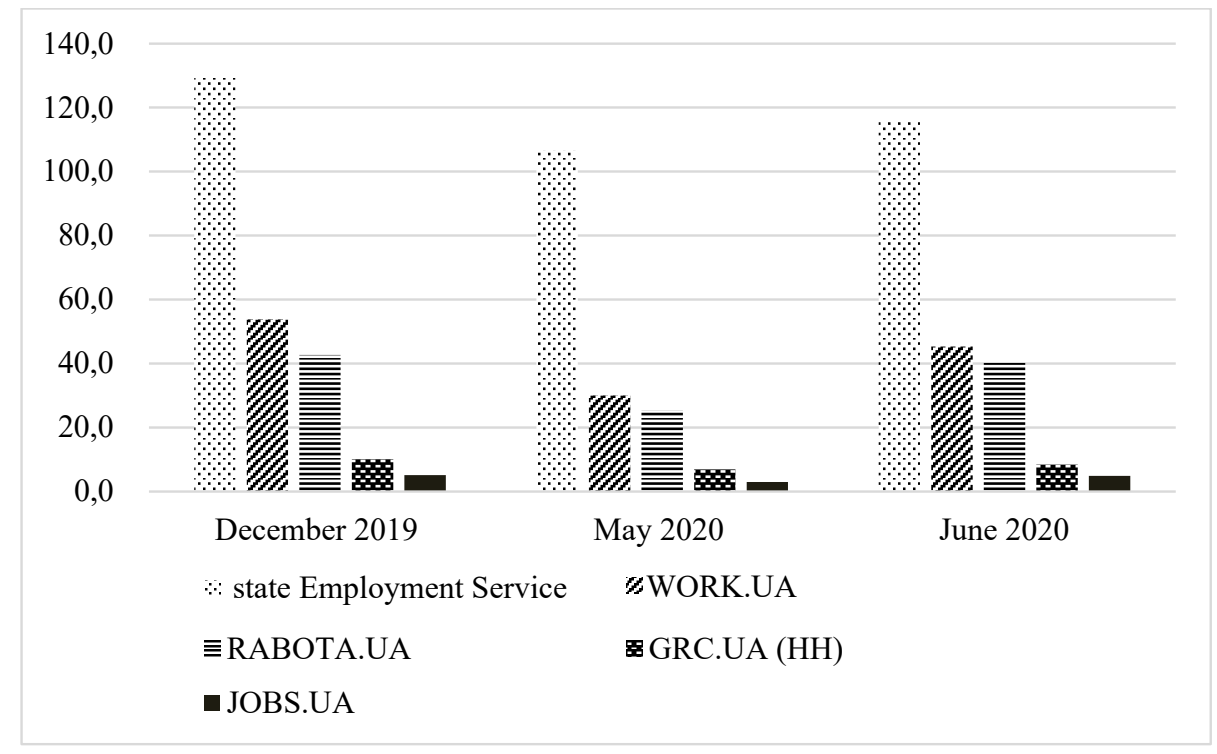

Figure 1. Number of vacancies according to the State Employment Service and job search and recruiting websites in the period, thousand units

Source: Source: compiled by the author according to the data of State Employment Service and the websites mentioned

a single information environment in the domestic labor market. At the same time, it is possible to include the data of private labor market intermediaries to the information support of the labor market only if the introduction and use of a single methodology for collecting and processing such data are based on the following elements. Information about vacancies on private websites is not always in the legal field due to the significant amount of shadow employment in the country and the intentions of employers to have informal relationships with employees. Private job search and recruiting websites are best suited for this, as the existing rules are the responsibility for the information about the vacancy by the entity that released it. The latter can directly affect the size of shadow employment and the presence of informal labor relations in the domestic labor market for a long time.

Given the limited number of job offers in the labor market in the legal sector of the economy, and in the absence of information about the full labor market, job seekers are in most cases forced to accept the informal job offers. According to the State Statistics Service of Ukraine, the number of informally employed people in Ukraine is over 3 million people (State Statistics Service of Ukraine: in 2020 - 3.2 million people, in 2019 and 2018 - 3.5 million people, in 2017 - 3.7 million people). Such data are crucial due to the fact that informally employed citizens not only work in the informal sector of the economy, but also periodically look for work, and therefore, in our opinion, such citizens find work in the labor market mainly through the private job search and recruiting websites. For example, in 2019, 1.4 million people posted their resumes on only one of the private job search and recruiting websites.

Since a significant part of job seekers and job offers are outside the registered labor market, it increases the scale of its asymmetry, affects the exacerbation of occupational imbalances. In addition, this condition gives rise to a restriction of competition, loss of social labor, inefficient use of material and human resources, conservation of the level of development of productive forces, low mobility of labor, its outflow abroad, etc.

Despite the fact that the Law of Ukraine "On Employment of Population" provides the public and private sectors with equal rights in the formation of state employment policy and defines their obligatory interaction, in practice, this rule does not work. In particular, the State Employment Service is obliged to form a database of vacancies (positions) on the basis of information received from business entities that provide employment mediation services, however, this is not regulated by bylaws and therefore there are no ways and forms of submission by private labor market intermediaries of information about vacancies received from employers. At the same time for various reasons, private labor market intermediaries are not interested in cooperating with the State Employment Service as streamlining this component of information support for labor market regulation is complicated by largescale shadow employment in Ukraine; this situation indirectly satisfies the private sector. The ILO project survey revealed only a small number of agencies (7\% of respondents) that stated their intention to cooperate with the State Employment Service, in particular by gaining access to a database of candidates, 
conducting training with the unemployed persons, implementing staff exchange programs (Vakhitova, 2013).

Digitalization of all economic processes in Ukraine is inevitable. Currently, the Ministry of Digital Transformation of Ukraine is working on a set of issues that bring social support and social protection of citizens closer through the digitalization of social services (Sylenko, 2020). At the same time, full functioning and development of the domestic labor market are impossible without legislative changes, in particular regarding the formation of single information support of the labor market on the basis of integration of information of public and private labor market intermediaries. It is proved that the transformation of economic processes includes the improvement of legislation and the legal system, it is "the most effective source of long-term economic growth and effectiveness of socio-economic policy" (Stroiko, 2021).

\section{Conclusions}

European integration aspirations determine Ukraine to develop and implement programs aimed at improving information society, including ensuring free access to global networks for further use of the received information in administrative management, education, health care, employment, and the labor market. Given the successful practices of Eastern European countries, Ukraine should introduce legislative regulation of the activity of private labor market intermediaries, job search and recruiting websites, digital platforms, and establish mutually beneficial information interaction of public and private mediation in this market in Ukraine. Then, after organizational, normative, and technical streamlining the information support of the labor market, it is necessary to connect data to the EURES system, including through the creation of the EURES Cross-Border Partnerships.

The prospect for further research will be aimed at developing a model of innovation of information support of labor market regulation, which takes into account the solution of problems and consequences of the current state of the labor market of Ukraine, in particular by introducing job seekers and job offers within the registered labor market with the exercise of further control over the registration of labor relations with employees.

\section{References:}

George A. Akerlof The Market for "Lemons": Quality Uncertainty and the Market Mechanism. The Quarterly Journal of Economics, v. 84, August 1970, p. 488-500.

Schneider Friedrich, The Shadow Economy and Work in the Shadow: What Do We (Not) Know? IZA DP, no. 6423. Bonn: Institute for the Study of Labor, March 2012, p. 73. Available at: http://ftp.iza.org/dp6423.pdf (accessed 14 June 2021).

Inna Irtyshcheva, Antonina Trushliakova, Ihor Sirenko (2020). Strategic human capital management in the context of digitalization. Baltic Journal of Economic Studies, 6 (5), 178-183. https://doi.org/10.30525/2256-0742/2020-65-178-183 (accessed 14 June 2021).

Hrishnova, O. A., \& Risnyi, O. P. (2017). Intehratsiia ukrainskoho rynku pratsi z yevropeiskym: zahrozy ta perspektyvy (otsinka na prykladi krain Skhidnoi Yevropy) [Integration of the Ukrainian labor market with the European one: threats and prospects (assessment on the example of Eastern European countries)]. Demohrafiia ta sotsialna ekonomika, 3 (31), 162-173.

Petrova, I. L. (1996). Rynok pratsi: protses sehmentatsii. Monohrafiia [Labor market: the segmentation process. Monograph]. Kyiv.

Lutai, L. A., Mishchenko, K. S., \& Tiulieniev, S. A. (2017). Upravlinska perebudova derzhavnoi sluzhby zainiatosti Ukrainy [Management restructuring of the state employment service in Ukraine]. Zhurnal Investytsii: praktyka ta dosvid, 2, 80-85. Available at: http://www.investplan.com.ua/pdf/2_2017/16.pdf (accessed 14 June 2021).

Ahmed Ghada. Private employment agencies in Morocco, Working Paper No. 283, International Labour Office, Sectoral Activities Programme. 2011. Geneva, ILO.

Abdusaidov, A. (2020). Organizational mechanism of interaction between the state and non-state employment structures in the labour market. Journal of Critical Reviews, 7, 11. Available at: http://www.jcreview.com/ fulltext/197-1592887723.pdf?1603751146 (accessed 14 June 2021).

Rymar, B. A. (2015). Poserednytstvo u sferi zainiatosti naselennia [Mediation in the sphere of employment]. Chasopys tsyvilistyky, 18, 109-113. Available at: http://dspace.onua.edu.ua/handle/11300/8342 (accessed 14 June 2021).

Prism'emploi - Rapport économique et social 2019. Available at: http://www.prismemploi.eu/Public/Page-daccueil/Documentation/Rapport-economique-et-social (accessed 14 June 2021).

Konventsiia pro pryvatni ahentstva zainiatosti Mizhnarodnoi orhanizatsii pratsi №181 vid 19.06.1997 roku [Convention on Private Employment Agencies of the International Labor Organization No. 181 dated June 19, 1997]. Available at: https://zakon.rada.gov.ua/laws/show/993_046\#Text (accessed 14 June 2021).

Saadia Zahidi. Four ways we can fix economics in 2019. Available at: https://www.weforum.org/agenda/2019/01/ four-ways-we-can-fix-economics-in-2019/ (accessed 14 June 2021). 
Mandl, I., Curtarelli, M., Riso, S., Vargas Llave, O., \& Gerogiannis, E. New forms of employment. European Union. Available at: https://www.eurofound.europa.eu/publications/report/2015/working-conditions-labour-market/ new-forms-of-employment (accessed 14 June 2021).

Rekomendatsiia shchodo pryvatnykh ahentstv zainiatosti Mizhnarodnoi orhanizatsii pratsi № 188 vid 19.06.1997 roku [Recommendation on Private Employment Agencies of the International Labor Organization No. 188 dated June 19, 1997]. Available at: https://zakon.rada.gov.ua/laws/show/993_292\#Text (accessed 14 June 2021).

Marchenko, I. S. (2013). Infrastrukturna pidtrymka rozvytku rynku pratsi Ukrainy: monohrafiia [Infrastructural support for the development of the labor market of Ukraine: monograph]. Kyiv.

Derzhavna sluzhba zainiatosti [State Employment Service]. URL: https://www.dcz.gov.ua (accessed 14 June 2021).

Derzhavna sluzhba statystyky Ukrainy. Demohrafichna ta sotsialna statystyka, rynok pratsi, zainiatist ta bezrobittia [State Statistics Service of Ukraine. Demographic and social statistics, labor market, employment and unemployment]. Available at: http://www.ukrstat.gov.ua/ (accessed 14 June 2021).

work.ua. Available at: https://www.work.ua/ (accessed 14 June 2021).

robota.ua. Available at: https://about.rabota.ua/ (accessed 14 June 2021).

grc.ua. Available at: https://grc.ua/ (accessed 14 June 2021).

jobs.ua. Available at: https://jobs.ua/ (accessed 14 June 2021).

Vakhitova, H. (2013). Pryvatni ahentsii zainiatosti v Ukraini / Mizhnarodna orhanizatsiia pratsi, Hrupa tekhnichnoi pidtrymky z pytan hidnoi pratsi ta Biuro MOP dlia krain Tsentralnoi ta Skhidnoi Yevropy. Budapesht. Available at: https://www.ilo.org/wcmsp5/groups/public/---europe/---ro-geneva/---sro-budapest/documents/publication/ wcms_244749.pdf(accessed 14 June 2021).

Alla Silenko, Vira Bezrodna, Olga Nikogosyan (2020). Digital economy as a factor in the development of a social state. Baltic Journal of Economic Studies, 6 (5), 155-162. Available at: http://baltijapublishing.lv/index.php/issue/ article/view/937 (accessed 14 June 2021).

Tetiana Stroiko, Ludmila Nazarova, Natalia Danik (2021). Transformation of economic processes on the basis of digitalisation. Baltic Journal of Economic Studies, 7 (1), 102-106. Available at: https://doi.org/10.30525/22560742/2021-7-1-102-106 (accessed 14 June 2021).

Povidomlennia komisii Yevropa 2020 - Stratehiia dlia rozumnoho, staloho ta vseokhopliuiuchoho zrostannia [Communication from Commission EUROPE 2020 - A strategy for smart, sustainable and inclusive growth]. Yevropeiska komisiia. Briussel, 2010.

Ievrostat. Indykatory Yevropy 2020. Yevropeiska sluzhba statystyky [Eurostat. Europe 2020 indicators. European Statistical Office]. Available at: http://ec.europa.eu/eurostat 